\title{
THE PROPERTIES OF SCREEN PRINTED (Bi,Pb)- Sr-Ca-Cu-O THICK FILMS BASED ON DECOMPOSED OXALATE POWDERS
}

\author{
J. HAGBERG \\ Microelectronics and Material Physics Laboratories, University of Oulu, SF-90570 Oulu, Finland \\ (Received November 15, 1992; in final form December 16, 1992)
}

The significance of powder and paste characteristics was studied in order to improve the morphology and structure of superconducting $(\mathrm{Bi}, \mathrm{Pb})-\mathrm{Sr}-\mathrm{Ca}-\mathrm{Cu}-\mathrm{O}$ screen printed thick films. Powder with nominal composition of $\mathrm{Bi}_{1.75} \mathrm{~Pb}_{0.4} \mathrm{Sr}_{1.9} \mathrm{Ca}_{2.1} \mathrm{Cu}_{3.2} \mathrm{O}_{\mathrm{y}}$ was prepared via the oxalate route and decomposed at 430 to $795^{\circ} \mathrm{C}$. The decomposed powders were characterized by $\mathrm{X}$-ray diffraction, transmission electron microscopy and specific surface area measurements. These studies showed a variation of specific surface area from 16.5 to $0.9 \mathrm{~m}^{2} / \mathrm{g}$ and a variation of the average particle size from $100 \mathrm{~nm}$ to $800 \mathrm{~nm}$ in the studied temperature interval. The phase structure showed three distinct temperature areas; between 430 to 620,620 to 715 , and at $795^{\circ} \mathrm{C}$.

Thick-film pastes were made by the addition of an organic vehicle at $500,620,650$ and $795^{\circ} \mathrm{C}$ to decompose annealed oxalate synthesized powders and, for comparison, the vehicle was also added to sintered mixed-oxide/carbonate-based powder in weight ratios from 0.42 to $0.54: 1$. Films were screen printed on single crystal $\mathrm{MgO}(100)$ substrates and melt annealed at 890 to $895^{\circ} \mathrm{C}$ for 3 min and subsequently, for prolonged diffusion, annealed at $852^{\circ} \mathrm{C}$. After firing, the films were mainly composed of the (001) textured $(\mathrm{Bi}, \mathrm{Pb})_{2} \mathrm{Sr}_{2} \mathrm{Ca}_{2} \mathrm{Cu}_{3} \mathrm{O}_{y}$ phase. The reference films, made from mixed oxide/carbonate powder, resembled the films based on oxalate powders decomposed at $795^{\circ} \mathrm{C}$. Films based on oxalate powders, decomposed at lower temperatures, were smoother and were able to carry noticeably higher currents than films based on powders decomposed at higher temperatures.

\section{INTRODUCTION}

The use of screen printed superconducting thick films in microelectronics (for example, transmission line patterns, sensors, microwave circuits, etc.) requires welldefined properties of both the functional powder of the paste and the paste itself, which is made by mixing the powdery material with an organic vehicle. Printing accuracy and smoothness of the printed films are important properties. Batch-tobatch repeatability, which depends on properties that are difficult to control such as vehicle properties, the powder morphology, and the ratio of vehicle to powder is also important. Previous studies have shown that in superconducting thick-film materials, the zero resistance temperature and critical current density are characteristics determined by the different stages of the fabrication process of the films, such as the method of powder preparation and the firing treatment of the printed films $[1,2,3]$.

The purpose of the present investigation was to study the decomposition of oxalate synthesised powder and the effect of variation of the powder and paste 
preparation parameters in order to achieve good printing accuracy and smooth $(\mathrm{Bi}, \mathrm{Pb})-\mathrm{Sr}-\mathrm{Ca}-\mathrm{Cu}-\mathrm{O}$ thick films on $\mathrm{MgO}(100)$ oriented single-crystal substrates with good current transport properties.

\section{EXPERIMENTAL PROCEDURE}

In oxalate synthesis, oxalic acid and nitrates of the cationic species of the powder composition were mixed together and the $\mathrm{pH}$ adjusted to 3.0 with ammonium hydroxide [3]. The resultant precipitate was filtered and dried. A nominal composition of $\mathrm{Bi}_{1.75} \mathrm{~Pb}_{0.4} \mathrm{Sr}_{1.9} \mathrm{Ca}_{2.1} \mathrm{Cu}_{3.2} \mathrm{O}_{\mathrm{y}}$ was used. The powders were decomposeannealed at $430,500,590,620,650,715$ and $795^{\circ} \mathrm{C}$, respectively for $12 \mathrm{~h}$ in an alumina crucible in ambient air. They were studied by transmission electron microscopy (TEM), Brunauer-Emmet-Teller method (BET), and X-ray diffraction (XRD). Also, one powder was prepared as a reference via the mixed oxide/carbonate route. $\mathrm{Bi}_{2} \mathrm{O}_{3}, \mathrm{PbO}, \mathrm{SrCO}_{3}, \mathrm{CaCO}_{3}$, and $\mathrm{CuO}$ powders were mixed and homogenized with ethanol in a ball mill for $2 \mathrm{~h}$, after which the mixture was dried, pelletized and calcined at $800^{\circ} \mathrm{C}$ for $12 \mathrm{~h}$. The pellets were then ground, mixed, pelletized and sintered at $845^{\circ} \mathrm{C}$ for $80 \mathrm{~h}$. The sintered pellets were ground and mixed again.

Four decompose-annealed powders were selected for further studies. These powders decomposed at $500,620,650$ and $795^{\circ} \mathrm{C}$ and the oxide/carbonate-based powders were mixed with the organic vehicle, which contained $90 \mathrm{wt} . \%$ terpineol, 6 wt. $\%$ ethyl cellulose and 4 wt. $\%$ antarox. The pastes were milled 20 times on a three roll paste mill to homogenise the mixtures. Films were printed through a 200 mesh screen on (100) oriented $\mathrm{MgO}$ single crystal substrates. After printing, they were kept at room temperature for $1 / 2 \mathrm{~h}$ for levelling of the film surface and were then dried at $140^{\circ} \mathrm{C}$ for $1 / 2 \mathrm{~h}$ and annealed at $400^{\circ} \mathrm{C}$ for $1 \mathrm{~h}$ to desorb any organic residues. The amount of organic vehicle was varied between 42 and $54 \mathrm{wt}$.\% from the weight of used powder. The amount of vehicles used for each paste is indicated in table 1. Each film was printed and handled in three different lots.

A two step firing procedure was used as in a previous study [1]. The films were melt annealed by heating at a rate of 1 to $2^{\circ} \mathrm{C} / \mathrm{min}$ up to $850^{\circ} \mathrm{C}$ and further at a rate of $5^{\circ} \mathrm{C} / \mathrm{min}$ up to $890-895^{\circ} \mathrm{C}$, where they were kept for $3 \mathrm{~min}$. The films were cooled down to $850^{\circ} \mathrm{C}$ at a rate of $2^{\circ} \mathrm{C} / \mathrm{min}$ and then to room temperature in the furnace. The slow heating rate to $850^{\circ} \mathrm{C}$ prevented an over-aggressive decomposition of the components in the film, which could have led to splashing of the film material. After melt annealing, the films were diffusion annealed at $852^{\circ} \mathrm{C}$ for 80 h. To prevent excessive evaporation of lead from the films, the firings were carried out under an inverted crucible along with fresh sintered powder of the same Bicompound.

Both the melted and the diffusion-annealed films were studied with scanning electron microscopy/energy dispersive X-ray spectrometry (SEM/EDS) and XRD; their thicknesses were measured and micrographs were taken using a light microscope. 
TABLE I

Phases detected by XRD for $\mathrm{Bi}_{1.75} \mathrm{~Pb}_{0.4} \mathrm{Sr}_{1.9} \mathrm{Ca}_{2.1} \mathrm{Cu}_{3.2} \mathrm{O}_{\mathrm{y}}$ powder decomposed at different temperatures. SSA corresponds to specific surface area and $\mathrm{D}$ to the average particle size as evaluated from the specific surface area and TEM observations. $X=$ strong reflection, $+=$ weak reflection, $-=$ no reflection. Last row indicates the weight percentage amounts of vehicle from the weight of powder used in the paste preparations.

\begin{tabular}{lccccccc}
\hline Decomposed $\left[{ }^{\circ} \mathrm{C}\right]$ & 430 & 500 & 590 & 620 & 650 & 715 & 795 \\
\hline $\mathrm{Bi}_{2} \mathrm{CuO}_{4}$ & $\mathrm{X}$ & $\mathrm{X}$ & $\mathrm{X}$ & $\mathrm{X}$ & + & - & - \\
$\mathrm{PbO}$ & + & $\mathrm{X}$ & $\mathrm{X}$ & $\mathrm{X}$ & - & - & - \\
$\mathrm{CuO}$ & + & $\mathrm{X}$ & $\mathrm{X}$ & $\mathrm{X}$ & $\mathrm{X}$ & $\mathrm{X}$ & + \\
$(\mathrm{Ca}, \mathrm{Sr}) \mathrm{CO}_{3}$ & - & $\mathrm{X}$ & $\mathrm{X}$ & + & - & - & - \\
$\mathrm{Ca}_{3} \mathrm{Bi}_{10} \mathrm{O}_{22}$ & - & - & - & + & $\mathrm{X}$ & $\mathrm{X}$ & - \\
$\mathrm{SrCO}_{3}$ & - & - & - & + & $\mathrm{X}$ & $\mathrm{X}$ & - \\
$\mathrm{Ca}_{2} \mathrm{PbO}_{4}$ & - & - & - & - & $\mathrm{X}$ & $\mathrm{X}$ & $\mathrm{X}$ \\
$\mathrm{Ca}-\mathrm{Sr}-\mathrm{Cu}-\mathrm{O}$ & - & - & - & - & + & + & $\mathrm{X}$ \\
$(\mathrm{Bi}, \mathrm{Pb})_{2} \mathrm{Sr}_{2} \mathrm{Cu}_{1} \mathrm{O}_{\mathrm{y}}$ & - & - & - & - & - & $\mathrm{X}$ & - \\
$(\mathrm{Bi}, \mathrm{Pb})_{2} \mathrm{Sr}_{2} \mathrm{Ca}_{1} \mathrm{Cu}_{2} \mathrm{O}_{\mathrm{y}}$ & - & - & - & - & - & - & $\mathrm{X}$ \\
$\mathrm{SSA}\left[m^{2} / \mathrm{g}\right]$ & 16.5 & 11.0 & 5.0 & 3.2 & 2.5 & 0.9 & 1.0 \\
$\mathrm{D}[\mathrm{nm}]$ & 100 & 150 & 250 & 300 & 400 & 650 & 800 \\
$\mathrm{Pastes}[\%]$ & - & $47,51,54$ & - & 50 & $42,47,51$ & - & 49 \\
\hline
\end{tabular}

The temperature dependence of resistivity and critical current density were measured for fired thick films. Pulsed currents with varying polarity were used. Contacts were made by pressing Au sheets on the film surface. The measurements were made on a film strip $1.2 \mathrm{~mm}$ long and $0.4 \mathrm{~mm}$ wide and the criterion of 1 $\mu \mathrm{V} / \mathrm{cm}$ for the superconducting state was established.

\section{THE STRUCTURE OF DECOMPOSED OXALATE POWDERS}

The phase existences, specific surface areas and averaged particle sizes for decomposed powders are presented in table 1 . According to XRD, below the decomposition temperature of $620^{\circ} \mathrm{C}, \mathrm{Bi}_{2} \mathrm{CuO}_{4},(\mathrm{Ca}, \mathrm{Sr}) \mathrm{CO}_{3}, \mathrm{PbO}$, and $\mathrm{CuO}$ phases existed in the powders. At and above $620^{\circ} \mathrm{C}$, oxide reactions and carbonate decomposition took place and powders decomposed above $620^{\circ} \mathrm{C}$ consisted primarily of $\mathrm{Ca}_{7} \mathrm{Bi}_{10} \mathrm{O}_{22}, \mathrm{SrCO}_{3}, \mathrm{Ca}_{2} \mathrm{PbO}_{4}$, and $\mathrm{CuO}$ phases. The powder decomposed at $715^{\circ} \mathrm{C}$ showed also reflections from $(\mathrm{Bi}, \mathrm{Pb})_{2} \mathrm{Sr}_{2} \mathrm{Cu}_{1} \mathrm{O}_{\mathrm{y}}$ phase. The powder decomposed at $795^{\circ} \mathrm{C}$ was primarily $(\mathrm{Bi}, \mathrm{Pb})_{2} \mathrm{Sr}_{2} \mathrm{Ca}_{1} \mathrm{Cu}_{2} \mathrm{O}_{\text {y }}$ phase. All the powders contained at least a small amount of $\mathrm{CuO}$. The oxide/carbonate-based reference powder was almost pure $(\mathrm{Bi}, \mathrm{Pb})_{2} \mathrm{Sr}_{2} \mathrm{Ca}_{2} \mathrm{Cu}_{3} \mathrm{O}_{\mathrm{y}}$ phase, as revealed by XRD.

The specific surface area decreased from $16.5-\mathrm{m}^{2} / \mathrm{g}$ for the powder decomposed at $430^{\circ} \mathrm{C}$ at increasing decomposition temperature down to about $1.0 \mathrm{~m}^{2} / \mathrm{g}$ for powders decomposed at and above $715^{\circ} \mathrm{C}$. The particle size varied from about 50 $\mathrm{nm}$ to $1 \mu \mathrm{m}$. The smaller particles formed agglomerates varying in size from 1.5 
to $8 \mu \mathrm{m}$ depending on the decomposition temperature, as observed by TEM. The average particle sizes indicated in table 1 were evaluated through TEM studies and specific surface area data.

The higher the decomposition temperature of the oxalate powder the rougher was the powder and consequently the lower was the amount of vehicle required to achieve the same viscosity level of thick-film paste. For powders decomposed at 500 and $650^{\circ} \mathrm{C}$, three vehicle weight ratios were tested; $0.47,0.51$ and $0.54: 1$, and $0.42,0.47$ and $0.51: 1$, respectively. The lower limits yielded pastes that were just printable whereas the upper limits yielded pastes that were much less viscous. For powders decomposed at 620 and $795^{\circ} \mathrm{C}$ and for the mixed oxide/carbonate powder, the vehicle-to-powder weight ratios were $0.50,0.49$, and $0.47: 1$, respectively.

\section{THE MICROSTRUCTURE OF FIRED FILMS}

After melt annealing, the films mainly consisted of $(\mathrm{Bi}, \mathrm{Pb})_{2} \mathrm{Sr}_{2} \mathrm{Ca}_{1} \mathrm{Cu}_{2} \mathrm{O}_{\mathrm{y}}$ phase as a matrix that contained bar-like $(\mathrm{Ca}, \mathrm{Sr})_{2} \mathrm{CuO}_{y}$ and $(\mathrm{Ca}, \mathrm{Sr})_{14} \mathrm{Cu}_{24} \mathrm{O}_{41}$ grains (Fig. 1). XRD showed a strong texture of 2212 phase with the c-axis perpendicular to the

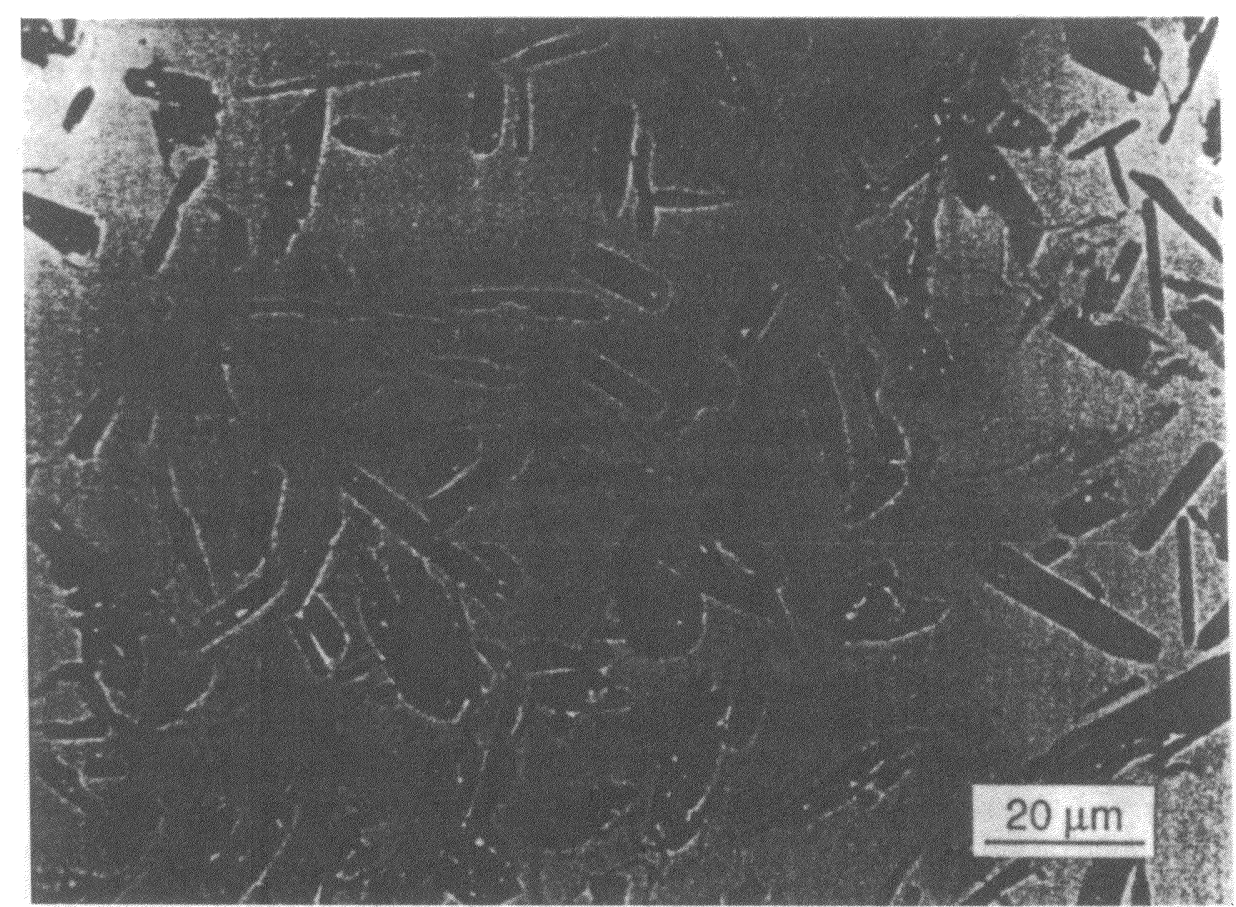

FIGURE 1 Backscattered electron image of film made from oxalate powder decomposed at $620^{\circ} \mathrm{C}$. The film was melt annealed at $895^{\circ} \mathrm{C}$ for $3 \mathrm{~min}$. The light matrix represents the $(\mathrm{Bi}, \mathrm{Pb})_{2} \mathrm{Sr}_{2} \mathrm{Ca}_{1} \mathrm{Cu}_{2} \mathrm{O}_{y}$ phase. Grey grains are $(\mathrm{Ca}, \mathrm{Sr})_{14} \mathrm{Cu}_{24} \mathrm{O}_{41}$ phase and dark grains $(\mathrm{Ca}, \mathrm{Sr})_{2} \mathrm{CuO}_{\mathrm{y}}$ phase. 


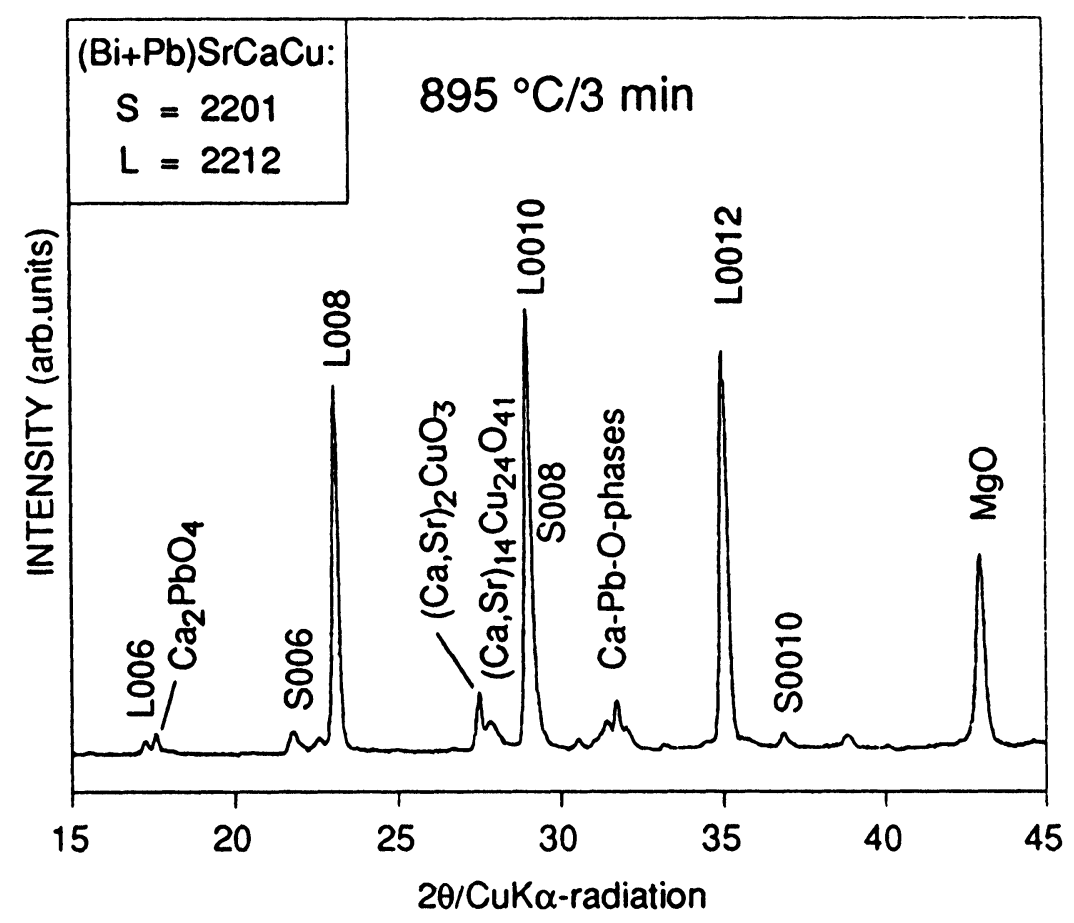

FIGURE 2 XRD-spectra of a thick film melt annealed at $895^{\circ} \mathrm{C}$ for $3 \mathrm{~min}$.

film surface (Fig. 2). In the XRD data plots, reflections of $\mathrm{Ca}-\mathrm{Pb}-\mathrm{O},(\mathrm{Ca}, \mathrm{Sr})_{2} \mathrm{CuO}_{\mathrm{y}}$ and $(\mathrm{Ca}, \mathrm{Sr})_{14} \mathrm{Cu}_{24} \mathrm{O}_{41}$ phases were also detected. The films, based on powders decomposed at 500 and $620^{\circ} \mathrm{C}$, were denser compared to those based on powders decomposed at higher temperatures. The size and amount of the $(\mathrm{Ca}, \mathrm{Sr})_{2} \mathrm{CuO}_{\mathrm{y}}$ bar-like grains were clearly dependent on the decomposition temperature used to prepare the powder. The higher the decomposition temperature the higher was the quantity but the smaller was the size of these bars (Fig. 3). The average size of the $(\mathrm{Ca}, \mathrm{Sr})_{2} \mathrm{CuO}_{\mathrm{y}}$ bar-like grains on the surface plane of the melted films, based on powders decomposed at $795,650,620$ and $500^{\circ} \mathrm{C}$, were $1.2 \times 8,1.5 \times 12,2.5$ $\times 20$ and $3 \times 40 \mu \mathrm{m}^{2}$, respectively. The $(\mathrm{Ca}, \mathrm{Sr})_{14} \mathrm{Cu}_{24} \mathrm{O}_{41}$ grains were usually larger and their quantity lower compared to that of the $(\mathrm{Ca}, \mathrm{Sr})_{2} \mathrm{CuO}_{y}$ grains. The higher the decomposition temperature of the powder the smaller was the quantity of the $(\mathrm{Ca}, \mathrm{Sr})_{14} \mathrm{Cu}_{24} \mathrm{O}_{41}$ crystals. Film thicknesses after melting varied between 6 and 17 $\mu \mathrm{m}$. The films prepared by using pastes with larger amounts of organic vehicle were thinner.

During diffusion annealing, the microstructure of the films was converted to contain mainly plate-like grains of the $(\mathrm{Bi}, \mathrm{Pb})_{2} \mathrm{Sr}_{2} \mathrm{Ca}_{2} \mathrm{Cu}_{3} \mathrm{O}_{\mathrm{y}}$ phase. From the XRD data, the volume fraction of $(\mathrm{Bi}, \mathrm{Pb})_{2} \mathrm{Sr}_{2} \mathrm{Ca}_{2} \mathrm{Cu}_{3} \mathrm{O}_{\mathrm{y}}$ phase was estimated to be between 70 and $90 \%$ and the films also had a strong (001) type texture. The films also consisted of minor amounts of $(\mathrm{Bi}, \mathrm{Pb})_{2} \mathrm{Sr}_{2} \mathrm{Ca}_{1} \mathrm{Cu}_{2} \mathrm{O}_{\mathrm{y}}$ and $(\mathrm{Bi}, \mathrm{Pb})_{2} \mathrm{Sr}_{2} \mathrm{Cu}_{1} \mathrm{O}_{\mathrm{y}}$ phases and unconverted $(\mathrm{Ca}, \mathrm{Sr})_{2} \mathrm{CuO}_{\mathrm{y}}$ and $(\mathrm{Ca}, \mathrm{Sr})_{14} \mathrm{Cu}_{24} \mathrm{O}_{41}$ phases. The amount 


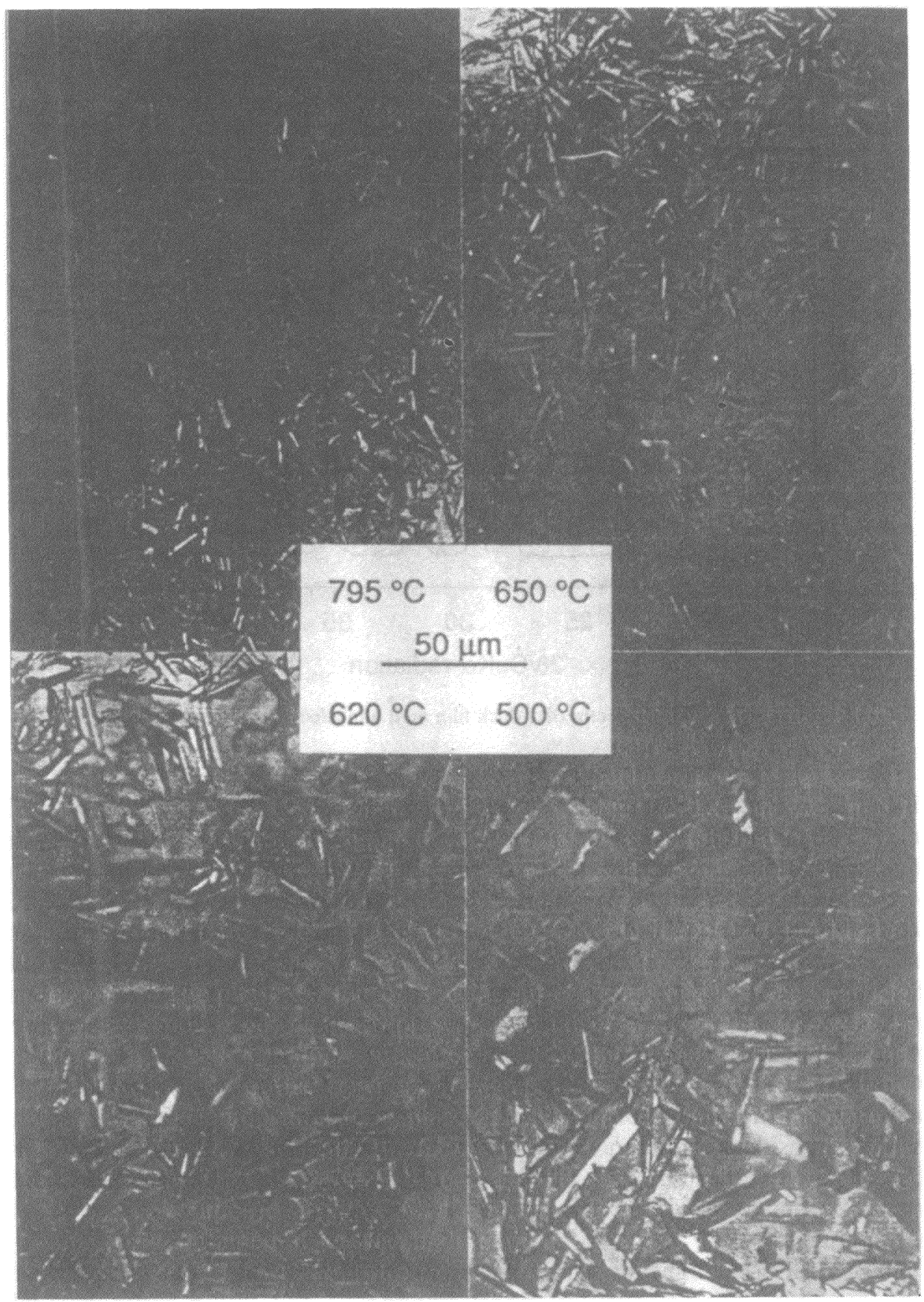

FIGURE 3 Optical photomicrographs of films based on oxalate powders decomposed at 500, 620, 659 and $795^{\circ} \mathrm{C}$ and melted at $895^{\circ} \mathrm{C}$ for $3 \mathrm{~min}$. $(\mathrm{Ca}, \mathrm{Sr})_{2} \mathrm{CuO}_{\mathrm{y}}$ and some $(\mathrm{Ca}, \mathrm{Sr})_{14} \mathrm{Cu}_{24} \mathrm{O}_{41}$ grains in a $(\mathrm{Bi}, \mathrm{Pb})_{2} \mathrm{Sr}_{2} \mathrm{Ca}_{1} \mathrm{Cu}_{2} \mathrm{O}_{\mathrm{y}}$ matrix can be seen. 
of the unconverted $\mathrm{Ca}-\mathrm{Sr}-\mathrm{Cu}$ oxides was higher in the films based on powders decomposed at higher temperatures. Clearly, the smoothest films were those based on the powder decomposed at $500^{\circ} \mathrm{C}$, especially when a larger amount of the vehicle was used in the paste preparation. These films also showed the strongest texture. In the films based on powders decomposed at higher temperatures, the plate-like $(\mathrm{Bi}, \mathrm{Pb})_{2} \mathrm{Sr}_{2} \mathrm{Ca}_{2} \mathrm{Cu}_{3} \mathrm{O}_{\mathrm{y}}$ grains were often protruding from the surface of the film and, in the worst case, formed holes in the films. The thickness of the films was found to increase during diffusion annealing by an average of 15 to $20 \%$ indicating density changes during phase transformations. The morphology of the reference film based on powder fabricated by the mixed oxide/carbonate route was similar to the film based on oxalate powder decomposed at $795^{\circ} \mathrm{C}$.

\section{ELECTRICAL PROPERTIES OF THE FILMS}

The film thickness, texture and transport current properties did not correlate with each other clearly. All the films studied consisted mainly of the correct superconducting phase. They had high superconducting transition temperatures (104 to 106 $\mathrm{K})$ and the resistivity behavior was metal-like. The highest critical current densities were obtained in films made using the paste based on oxalate powders decomposed at 500 and $620^{\circ} \mathrm{C}$ with vehicle/powder proportion 0.54 and $0.50: 1$. In these films, critical current densities of $3.0 \times 10^{3} \mathrm{~A} / \mathrm{cm}^{2}$ and $1.4 \times 10^{3} \mathrm{~A} / \mathrm{cm}^{2}$, respectively were achieved at $77 \mathrm{~K}$. All other films, including the mixed oxide/carbonate powder-based films, had critical current densities of $0.6 \times 10^{3} \mathrm{~A} / \mathrm{cm}^{2}$ or less at $77 \mathrm{~K}$. Oxalate powder, decomposed at $500^{\circ} \mathrm{C}$, seems to be the most favorable for melt processing. In addition to being the finest powder, it is believed that its phase structure prefers the most flattened and the densest films after firing.

The properties of the films at different lots varied. For example, for the films based on $500^{\circ} \mathrm{C}$ decomposed oxalate powder, the critical current densities at $77 \mathrm{~K}$ varied between 1.2 to $3 \times 10^{3} \mathrm{~A} / \mathrm{cm}^{2}$. However, the differences of film properties within each lot were similar. The variations of film properties between different lots can be attributed mainly to the variations in the temperature fluctuations during firings. The target temperature for melt annealing was $895^{\circ} \mathrm{C}$ and for diffusion annealing $852^{\circ} \mathrm{C}$, but these varied slightly, dependent on the properties of the furnace used. Also, a part of the variations of properties in films can be explained by the variations in the printing and handling processes.

The temperature dependence of critical current density of one of the best films is presented in Fig. 4. With increasing temperature, it had a linearly decreasing trend up to $70 \mathrm{~K}$, after which it showed a clear deflection to a more abrupt decrease. All measured films showed this behavior. It could be postulated that it originates from the $(\mathrm{Bi}, \mathrm{Pb})_{2} \mathrm{Sr}_{2} \mathrm{Ca}_{1} \mathrm{Cu}_{2} \mathrm{O}_{\mathrm{y}}$ impurity phases at the grain boundaries or in the grains themselves.

\section{CONCLUSIONS}

The increasing decomposition annealing temperature of oxalate-synthesised precursor powder caused an increase in the average particle size resulting in a decrease 


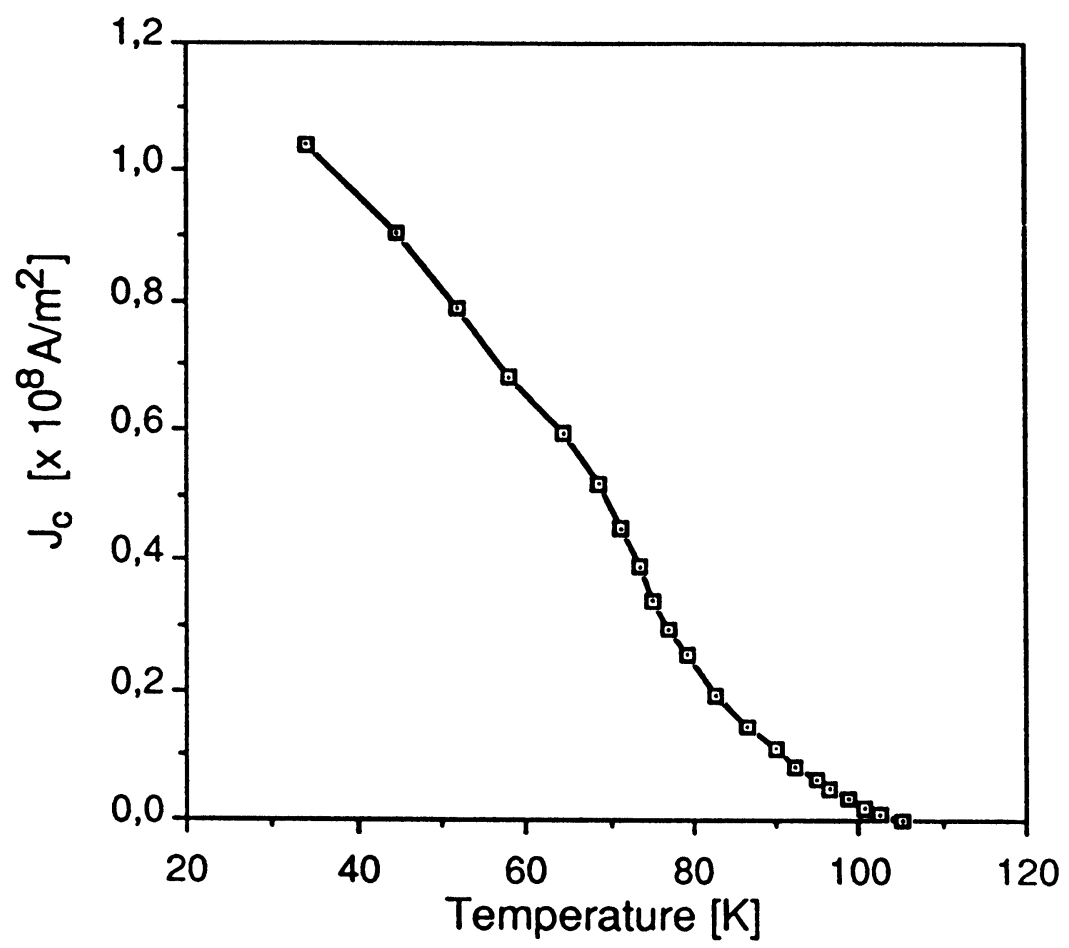

FIGURE 4 The critical current density as a function of temperature for a film based on powder decomposed at $620^{\circ} \mathrm{C}$. The film was melt annealed at $895^{\circ} \mathrm{C}$ for $3 \mathrm{~min}$ and diffusion annealed at $852^{\circ} \mathrm{C}$ for $80 \mathrm{~h}$.

of the specific surface areas. Three distinct phase areas for the decomposition of oxalate synthesised powder were found, between 430 to 620 , between 620 to 715 and at $795^{\circ} \mathrm{C}$.

Preparation of thick films based on powders decomposed at temperatures of 500 and $620^{\circ} \mathrm{C}$ resulted in the smoothest surface and the smallest amounts of $(\mathrm{Ca}, \mathrm{Sr})_{2} \mathrm{CuO}_{y}$ phase on a single-crystal $\mathrm{MgO}(100)$. The amount of organic vehicle in the paste, in addition to the type of powder used, affected the film thickness and, to a lesser extent, the smoothness of the annealed films. The films, based on powder decomposed at $500^{\circ} \mathrm{C}$ with vehicle/powder proportion $0.54: 1$, were the thinnest, the thickness being about 6 to $7 \mu \mathrm{m}$; these showed a stronger texture than the other films. They were also the best films as determined from the electrical measurements. The morphology of the reference films based on the mixed oxide/ carbonate route of powder manufacture was similar to the films based on oxalate powder decomposed at $795^{\circ} \mathrm{C}$.

Transport properties varied noticeably in these films, being, at their best $(3.0$ $\times 10^{3} \mathrm{~A} / \mathrm{cm}^{2}$ ) in the film based on powder decomposition annealed at $500^{\circ} \mathrm{C}$. This powder was composed of $\mathrm{Bi}_{2} \mathrm{CuO}_{4},(\mathrm{Ca}, \mathrm{Sr}) \mathrm{CO}_{3}, \mathrm{PbO}$ and $\mathrm{CuO}$ phases, as revealed by XRD. 


\section{REFERENCES}

1. J. Hagberg, R. Rautioaho, J. Levoska, A. Uusimäki, T. Murtoniemi, T. Kokkomäki and S. Leppävuori, Materials Letters 9, 5-9 (1989).

2. A. Uusimäki, I. Kirschner, J. Levoska, J. Hagberg, G. Zolt, Gy. Kovacs, T. Porjesz, I. Dodony, S. Leppävuori, E. Lähderanta and R. Laiho, Cryogenics 30, 593-598 (1990).

3. I. Kirschner, S. Leppävuori, R. Laiho, I. Albfeder, I. Dodony, A. Uusimäki, T. Porjesz, J. Hagberg, Gy. Kovacs, E. Lähderanta, A. Voladin, and G. Zsolt, Z. Physik B85, 175-186 (1991).

4. J. Hagberg, A. Uusimäki, J. Levoska and S. Leppävuori, Physica C 160, 369-374 (1989). 

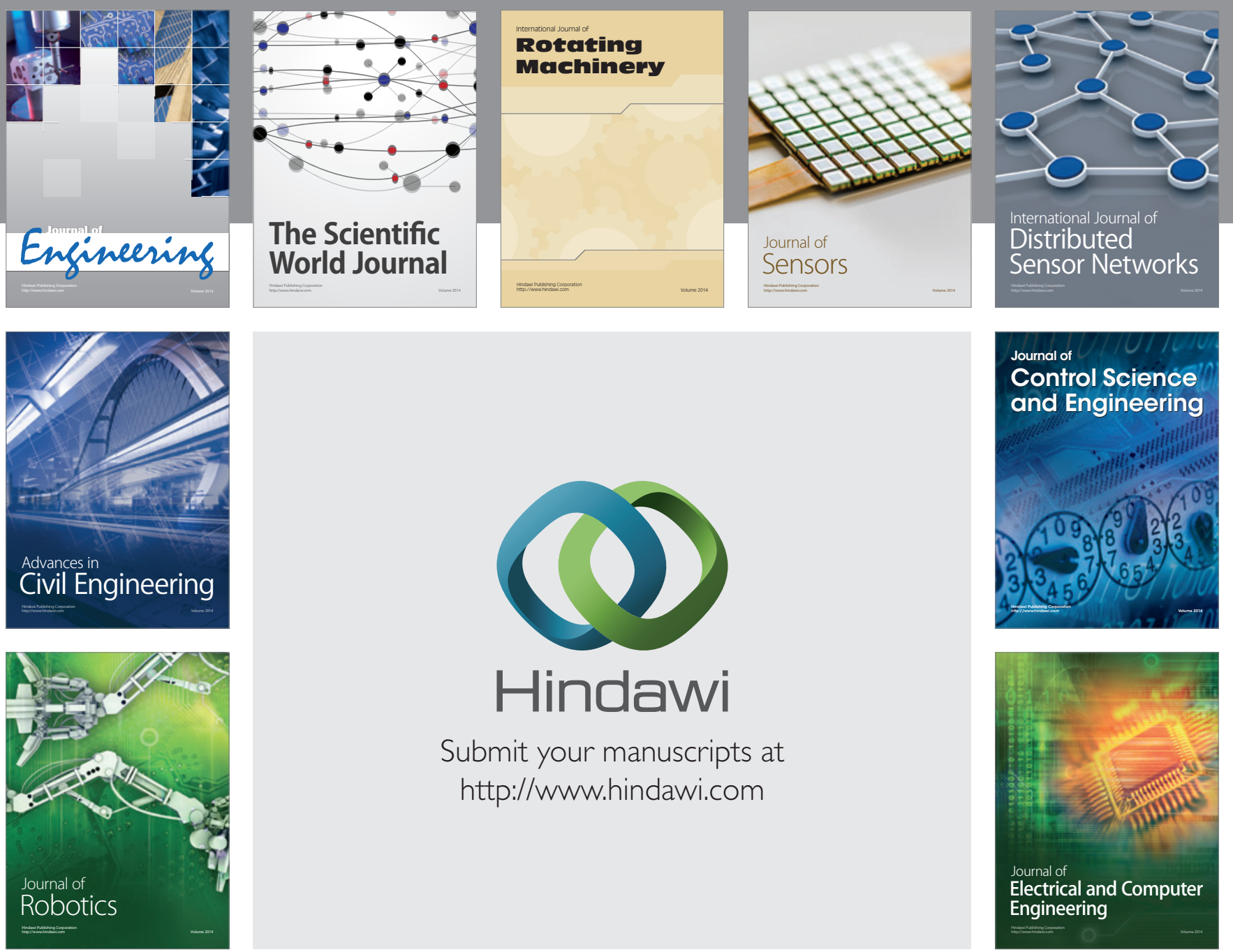

Submit your manuscripts at

http://www.hindawi.com
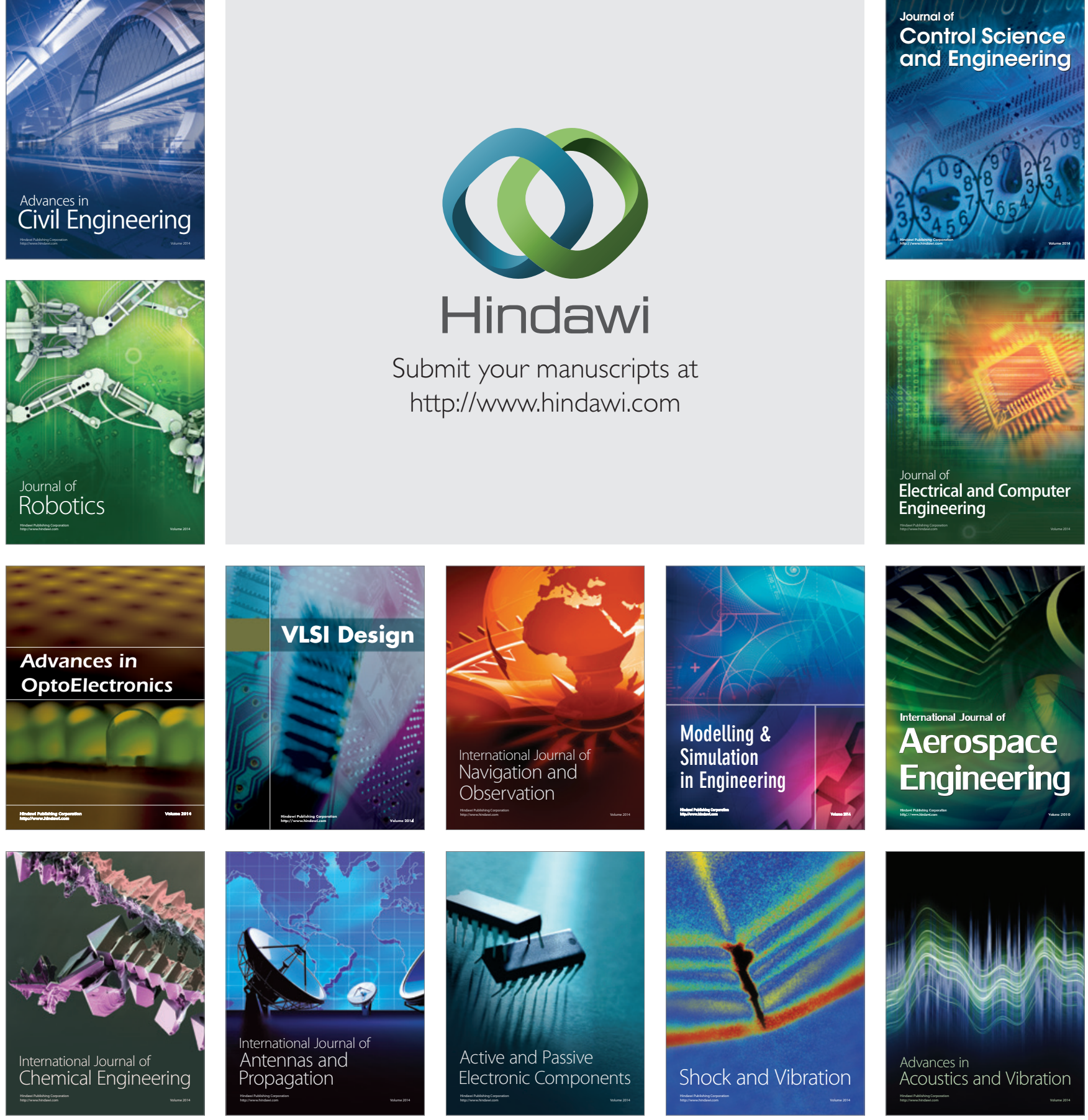